\title{
CASTAÑEDA'S QUASI-INDICATORS AND THE TENSED THEORY OF TIME*
}

\section{QUENTIN SMITH}

University of Indiana

\section{Castañeda's Theory of Temporal Quasi-Indicators}

One of the mcst influential theories in the philosophy of language in the past two or three decades is Castañeda's theory of quasi-indicators. ${ }^{1}$ According to this theory, locutions such as

- I am grateful to William F. Vallicella for helpful comments on an earlier draft.

1 Most of the articles in which this theory is expounded are referenced in the Bibliography in James E. Tomberlin (ed.), Agent, Language, and the Structure of the World, (Hackett, 1983), pp. 467-476. See especially items 45-48, 56-57, 67, and 119. Castañeda's theory has influenced or been discussed by such philosophers as Roderick Chisholm, The First Person (University of Minnesota Press, 1981); Jerry Fodor, The Language of Thought (Harvester, 1976); Patrick Grim, “Against Omniscience”, Nous 19 (1985): 151-180; David Lewis, "Attitudes De Dicto and De Se", The Philosophical Review 87 (1979): 513-543; John Perry, "The Problem of the Essential Indexical", Nous 13 (1979): 3-21; Lynn Rudder-Baker, "On Making and Attributing Demonstrative Reference", Synthese 49 (1981): 245-279; Stephen Schiffer, "The Basis of Reference, Erkentnis 13 (1978): 171-206, and Eddy Zemach, "De Se and Descartes", Nous 19 (1985): 181-204.

In this article my presentation and evaluation of Castañeda's theory of temporal quasi-indicators is based on his two classic articles from 1967, "Indicators and Quasi-Indicators", American Philosophical Quarterly 4 (1967): 85-100 and "Omniscience and Indexical Reference", The Journal of Philosophy 64 (1967): 203-209, both reprinted in Castañeda's Thinking, Language, Experience (University of Minnesota Press, 1989), referred to in the main body of my article as TLE. (Castanieda's article on omniscience is a response to Norman Kretzmann's "Omniscience and Immutabi- 
"he himself", "then" and "there" are used as quasi-indicators when they represent in indirect speach someone's uses of indicators, such as "I", "now" and "here". For example, "then" in "At $t_{1}$, Jones knows (tenselessly) that the storm is (tenselessly) approaching then" represents Jones' use of "now" in his utterance at $t_{1}$ of "The storm is now approaching". My purpose in this paper is to confront Castañeda's theory of the temporal quasi-indicator "then" with the tensed theory of time and to conclude from this confrontation that Castañeda's theory requires substantial modifications.

Castañeda ascribes to quasi-indicators the following properties, among others: (i) they do not express indexical (indicator) references made by the speaker, (ii) they require an antecedent to which they refer back (as "then" refers back to "at $t_{1}$ "), but are not replaceable by their antecedents, (iii) they are not intersubstitutable with names or descriptions and (iv) they "represent uses" of indexicals by somebody $p$, such that they are means of making $p$ 's "indexical reference both interpersonal and enduring, yet preserving it intact" [TLE 207]. Castañeda understands (iv) to entail that a sentence containing a quasiindicator is such that its embedded oratio obliqua clause (e.g. "the storm is [tenselessly] approaching then") expresses the proposition that was originally expressed by the relevant sentence-utterance containing the indicator (e.g. Jones utterance at $t_{1}$ of "The storm is now approaching"). ${ }^{2}$

lity", The Journal of Philasophy 63 (1966): 409-421.) Due to limitations of space, I shall not attempt to explain and evaluate the very different theory of temporal quasi-indicators that emerges in Castañeda's latter writings. (See, for example [TLE 132-136] and the implications for temporal quasiindicators of Castañeda's remarks on pages 156-159.) It is Castañeda's early theory of quasi-indicators, his 1960 s theory, that (to-date) has excercised the most profound influence on contemporary philosophy of language and for this reason is worthy of explanation and evaluation in its own right.

2 This interpretation of Castaneda is textually substantiated in sections 2 and 3. 
The tensed theory of time may be briefly defined as the theory that a use of a logically contingent tensed sentence, such as "The storm is now approaching", expresses a proposition that (a) ascribes a monadic property of presentness, pastness or futurity and (b) cannot be expressed by a tenseless locution.

Castañeda's theory of temporal quasi-indicators is inconsistent with the tensed theory of time since it entails the negations of (a) and (b). As I have stated, his theory implies that a use of "The storm is now approaching" at $t_{1}$ by Jones expresses the same proposition that is expressed by the embedded oratio obliqua clause in

(1) At $t_{1}$, Jones knows (tenselessly) that the storm is (tenselessly) approaching then.

Since the embedded clause is tenseless, Castañeda's theory is inconsistent with the position (b) that propositions expressed by tensed sentence-utterances cannot be expressed tenselessly. And since (1), if true at all, is true whenever it is uttered, (1) cannot ascribe a monadic property of presentness (or pastness, or futurity) to $t_{1}$ or the storm's approach. Thus, Castaneda's theory is also inconsistent with position (a), for if (1) does not ascribe one of these properties and a part of (1) expresses the proposition expressed by the tensed sentence-utterance, the proposition expressed by the tensed utterance does not ascribe one of these properties.

Castañeda's theory of temporal quasi-indicators implies a theory of temporal indicators endorsed by many proponents of the tenseless theory of time, the theory that temporal indicators directly refer to particular times (" $B$-positfons", as they are called in the literature) and do not ascribe to them transitory temporal properties (" $A$-properties"). ${ }^{3}$ In line with this

3 Some detensers have adopted Castañeda's theory as a central part of their tenseless theory of time. See for example L. Nathan Oaklander, Temporal Relations and Temporal Becoming (University Press of America, 1984), p. 127. George Schlesinger, although inclined towards the tensed theory 
tenseless theory, Castañeda writes that "reference to an entity by means of an indicator is purely referential, that is, it is a reference that attributes no property to the entity in question" [TLE 207].

It seems to me however, that there is a sound argument that Castañeda's theory of temporal quasi-indicators is not adequate to the protophilosophical data about "now" and "then" and that the theory of temporal quasi-indicators must be modified to the point where it is consistent with the tensed theory of time. I shall present this argument in terms of Castañeda's most detailed example involving temporal indicators and quasiindicators, that involving the height of the Chrysler Building in his article on "Omniscience and Indexical Reference" [TLE 137-143].

\section{The Nonrepresentation of "Now" by "Then"}

Suppose that at $t_{1}$, the height of the Chrysler Building is 1,046 feet and at $t_{2}$ it is extended, by the addition of an antenna, to 1,086 feet:

the question... is whether or not a person can know at time $t_{1}$ (prior to the extension of the antenna) a proposition that he would express at $t_{2}$ (after the extension) by uttering a sentence containing an indicator, e.g. 'Now the Chrysler Building is 1,086 feet tall.'... [T] he answer is 'yes', and a way of finding one formulation of that proposition is the method illustrated above, in which we employed principle $(P)$. Thus, suppose that

(11) Kretzmann knows at $t_{1}$ that: Chrysler Building is 1, 046 feet high at $t_{1}$, and at $t_{2}$ it will have a 40-foot antenna extended from its tip, and that the man who makes the extension knows at $t_{2}$ that the Chrysler Building is 1,086 feet high then.

Clearly, if (11) obtains, Kretzmann knows of the change in hoight without having to change his knowledge [TLE 142].

of time, shows some symphaty for Castañeda's theory; see Schlesinger's Aspects of Time (Hackett, 1980), p. 135. 
Principle $(P)$ is

$(P)$ If a sentence of the form ' $X$ knows that a person $Y$ knows that...' formulates a true statement [proposition], then the person $X$ knows the statement formulated by the clause filling the blank '...'.

If $(11)$ and $(P)$ are both true, does Kretzmann know at $t_{1}$ the proposition that the man who makes the extension (call him $M$ ) would express at $t_{2}$ by uttering "Now the Chrysler Building is 1,086 feet tall"? Although Castañeda's answer is affirmative, I believe the answer should be negative, for what Ktetzmann relevantly knows at $t_{1}$, according to (11), viz., that the Chrysler Building is 1,046 feet at $t_{1}$ and that the man who makes the extension knows at $t_{2}$ that the Chrysler Building is 1,086 feet high then, does not entail

(2) The Chrysler Building is 1,086 feet tall at the present time.

On the other hand, what $M$ knows by knowing the proposition expressed at $t_{2}$ by "Now the Chrysler Building is 1,086 feet tall" does entail (2). But the reason for the nonentailment of (2) by what Kretzmann knows at $t_{1}$ is not that Kretzmann's knowledge entails

(3) The Chrysler Building is 1,046 feet tall at the present time.

What Kretzmann knows at $t_{1}$ does not entail (3) either, since that $t_{1}$ is present or that his time of knowing is present is not a part of what he knows at $t_{1}$ (or at least it is not a part of what is reported by (11), which is the only knowledge possessed by Kretzmann that is under consideration). The reason Kretzmann's knowledge does not entail (2) is instead that his knowledge is devoid of any information about which time is present. It is precisely this knowledge that is omitted when the "now" 
in $M$ 's utterance is replaced by the "then" in the oratio obliqua construction (11).

I believe the reason that "then" does not preserve intact the semantic content of "now" is that "then" preserves merely the "now's" reference to a $B$-position, the time $t_{2}$, and omits the "now's" reference to the $A$-property of presentness and the ascription of this property to $t_{2}$. I admit that additional argumentation is needed to establish that this is the only possible explanation of the failure of "then" to preserve intact the semantic content of the "now". 4 But it is sufficient for my present limited purposes to show that Castañeda's theory of tenseless quasiindicator constructions cannot explain certain protophilosophical data that can be explained by the tensed theory of time. Establishing this shows that, in respect of these data, the tensed theory of time can be successfully defended against the threat posed by Castañeda's theory. But clearly this defence needs to be strengthened.

\section{The Difference Between Quasi-Indicators and Indicator- Ascribers}

It might be objected that my above criticism is based on a misunderstanding of Castañeda's theory of quasi-indicators. Such an objection might be made on the basis of Patrick Grim's (mostly) well-argued and perceptive article "Against Omniscience: The Case from Essential Indexicals"5 in which he denies that Castañeda's theory implies that the indexical propo-

4 I have argued elsewhere that the view that uses of "now" refer to $B$-times and ascribe to them the monadic $A$-property of presentness is the only view consistent with all the linguistic data about "now". See Quentin Smith, "Problems with the New Tenseless Theory of Time", Philosophical Studies 52 (1987): 371-392; "The Co-Reporting Theory of Tensed and Tenseless Sentences", The Philosophical Quarterly 40 (1990): 223-232, and "Temporal Indexicals", Erkenntnis, forthcoming.

5 Patrick Grim, "Against Omniscience: The Case from Essential Indexicals", Nous 19 (1985): 151-180. I hereafter refer to this article as AO. 
sitions are expressed by the oratio obliqua clauses containing the quasi-indicators. According to Grim, Castañeda does not hold "that what is expressed at one time using an indexical can itself be expressed at another time using a quasi-indicator in oratio recta" [AO 164]. This is perfectly true, but Grim erroneously concludes from this that "Castanieda holds that the fact that someone knows something that they might express using an indexical is a fact that can be expressed by others or at another time using a quasi-indicator in oratio obliqua" [AO 164]. But Castañeda does not hold this but instead that what is expressed at one time using an indexical can itself be expressed at another time using a quasi-indicator in oratio obliqua. This is precisely what is entailed by Castañeda's above-quoted statement that "a person can know at time $t_{1} \ldots$ a proposition that he would express at $t_{2} \ldots$ by uttering a sentence containing an indicator [viz., 'now']... and... one formulation of that proposition [is found in the oratio obliqua construction (11)]". If Grim's interpretation were correct, this quotation would have read instead "a person can know at time $t_{1}$, not the proposition that he would express at $t_{2}$ by uttering a sentence containing 'now', but merely the fact that he knows at $t_{2}$ a proposition that he would express at $t_{2}$ by uttering a sentence containing 'now' "... and one formulation of the fact that he knows at $t_{2}$ that proposition [is found in the oratio obliqua construction (11)].

Grim's analysis of Castañeda's theory is in addition self-contradictory, for a criticism of Castañeda's theory he subsequently develops is sound only if his interpretation of Castañeda is false. A consideration of this criticism is important since it will enable us to deepen our criticism and develop a new semantic category, that of indicator-ascribers. Grim supposes that it is 10:00 and that he knows that

(4) The meeting is starting now

and that $\mathrm{McQ}$ knows that 
(5) At 10:00 Patrick Grim knows (tenselessly) that the meeting is (tenselessly) starting then.

Grim then claims that Castañeda is mistaken in supposing that "what I know in knowing (4) is also something that McQ would know in virtue of knowing (5)" [AO 167], since McQ "may not know that the meeting is starting now - simply because McQ may not know that it is now 10:00-" [AO 167]. But if Grim's interpretation of Castañeda were correct, and mine incorrect, this criticism would be incorrect. For if Grim's interpretation were correct, Castañeda's position would not be that McQ knows what Grim knows, but that McQ knows merely the fact that Grim knows at 10:00 a proposition that is expressible at 10:00 by "the meeting is starting now", and this is consistent with McQ not knowing the proposition itself, i.e. not knowing what is expressible at 10:00 by "the meeting is starting now".

Grim's inconsistent treatment of Castañeda's theory is nevertheless fruitful, for it suggests there is a semantic category different than Castañeda's category of quasi-indicators, the category (that I shall call) indicator-ascribers. Whereas a sentence containing a quasi-indicator expresses (by virtue of its embedded clause in indirect speech) the proposition expressed by a use of a sentence containing an indicator, a sentence containing an indicator-ascriber expresses instead the fact that someone expressed a proposition by using a sentence containing an indicator. If we identify facts with true propositions, then we may say that a sentence containing an indicator-ascriber expresses the proposition that someone expressed a proposition by using a sentence containing an indicator (of a specified sort). The notions of a quasi-indicator and an indicator-ascriber will be developed in the next section within the context of the tensed theory of time.

But first let us ask if Castañeda's theory of "then" and "now" can be rendered sound if revised to accord with Grim's interpretation, so that it becomes the theory that "then" (in my new 
terminology) is not a quasi-indicator but an indicator-ascriber. I think that the revised theory is also unsound, for "then" does not ascribe uses of "now". (5) does not entail that Grim knew at 10:00 something he would then express by "the meeting is starting now", for (5) is consistent with

(6) At 10:00 Patrick Grim knows (tenselessly) that the meeting is (tenselessly) starting then, but at 10:00 he does not know what he would express then by the sentence "The meeting is starting now".

This can be shown if we vary upon one of Grim's ingenious examples. Suppose that it is 10:00 and that Grim is viewing a video tape of the meeting's start and believes de re of the time shown on the screen that the meeting is (tenselessly) starting at that time. The events depicted on the screen are in fact occurring at 10:00, since they are occurring simultaneously with their being taped and displayed to Grim. These facts suffice to render (5) true, for they entail that at 10:00 Grim knows that the meeting is (tenselessly) starting then. But suppose Grim does not realize that the events displayed on the video screen are simultaneous with his witnessing of them; he believes, mistakenly, that they occurred earlier. Grim therefore believes, at 10:00, what he could then express by "The meeting is not starting now".

This suggests that Castañeda's "then" is in truth a quasiindicator that captures references made by tenseless indexical descriptions of or references to times, such as "at that time", "on this date", and "then" (used as an indexical rather than a quasi-indicator). For example, "then" in (5) captures Grim's reference to 10:00 that he might then express by saying "The meeting is starting at that time". Uses of such tenseless indexical expressions as "at that time" are de re and refer directly to a $B$-position, without attributing to it an $A$-property. 


\section{Tensed Quasi-Indicators and Tensed Indicator-Ascriber}

Instances of the category of tensed quasi-indicators can be identified if we reject Castañeda's fundamental principle that indicators in indirect speech never function as quasi-indicators. Castañeda writes that "indicators in oratio obliqua express indexical references by the speaker, and leave it open whether the person spoken about refers to the same objects indexically or not" [TLE 139]. But the following example, among others, suggests that this principle is mistaken. Suppose that Jones utters with truth at noon, June 17, 1989, "The Chrysler Building is now 1,086 feet tall", and that Brown also utters with truth at this time

(7) It is now noon, June 17, 1989 and Jones now knows that the Chrysler Building is now 1,086 feet tall.

I suggest that the third occurrence of "now" in Brown's utterance of (7) both expresses the speaker's indexical reference to noon and functions as a quasi-indicator by purporting to and succeeding in capturing the semantic content of Jone's indexical reference to noon. If Brown's utterance of (7), call it $U$, neither purported to nor succeeded in doing this, $U$ would not have the truth conditions it in fact has, for $U$ is true only if Jones refers to noon indexically. If Jones refers to noon nonindexically via a description or a name, the $U$ would be false, for if Jones had access to noon through nonindexical descriptions or names only he would not know that it is now noon and that this is when the Chrysler Building is 1,086 feet tall. For instance, if Jones knew merely that the Chrysler Building is 1,086 feet tall at whatever time is noon, June $17,1989, U$ would be false, since this knowledge does not include the knowledge that the Chrysler Building is now this tall. Secondly, if Jones knew merely that the Chrysler Building is 1,086 feet tall at $T$, where " $T$ " is a name of noon, June $17,1989, U$ would also be false, for this knowledge does not include the knowledge that the Chrysler 
Building is now 1,086 feet tall. $U$ is true only if Jones refers to noon in a way that he could or does express at noon by saying "The Chrysler Building is now 1,086 feet tall".

If the third occurrence of "now" in (7) is a quasi-indicator, then some of Castañeda's four characteristics of quasi-indicators (listed in section 1) can no longer be taken as definitive of quasi-indicators. This is not surprising, since some of these characteristics hold only of tenseless quasi-indicators and presuppose a tenseless theory of time. Consider the fourth characteristic, that quasi-indicators are means of making somebody's "indexical reference both interpersonal and enduring". This is false because of the second conjunct; the quasi-indicator "now" in (7) does not make Jones' indexical reference to noon enduring since this quasi-indicator captures Jones indexical reference only at noon. If (7) is uttered one hour later, at 1:00, the three occurrences of "now" then refer to $1: 00$, not noon, and (7) as uttered then is false.

Consider also the first characteristic I listed, that quasi-indicators do not express indexical references made by the speaker. If this means that occurrences of words that have the property of being quasi-indicators do not have the property of expressing speakers' indexical references, it is false, since the third occurrence of "now" both expresses the speaker's indexical reference and captures Jones' indexical reference.

The second characteristic I listed, that quasi-indicators require an antecedent to which they refer back, is also inapplicable, since the antecedent of (7) can be eliminated. This deprives us of some temporal information about Jones' indexical reference but it does not prevent the last occurrence of "now" in (7) from being a quasi-indicator. If I utter at noon, "Jones now knows that the Chrysler Building is now 1,086 feet tall", the second "now" both expresses my indexical reference to noon and purports to capture Jones' indexical reference to noon, as a suitably modified version of the above argument about the truth conditions of $U$ would show. 
But Castañeda's third characteristic, that quasi-indicators are not intersubstitutable with names or descriptions, remains acceptable, as is suggested by my argument about the truth conditions of $U$.

Past or future uses of "now" cannot be semantically captured by presently used quasi-indicators but can be presently represented only by indicator-ascribers. Suppose it is now 1:00 and I want to say something about what Jones knew at noon when he said "The Chrysler Building is now 1, 086 feet high". Suppose also that I know now, at 1:00, that the Chrysler Building is not now 1,086 feet high. I may say

(8) When noon, June 17, 1989 was present, Jones knew of this time that it was present and that it was occupied by the Chrysler Building's being 1, 086 feet high.

By virtue of knowing (8), I do not know what Jones knew at noon and then expressed by "The Chrysler Building is now 1,086 feet high", for by virtue of knowing (8) I do not know that this height of the building has presentness. (8) entails merely that this height had presentness. Indeed, I know it does not have (present tense) presentness, for I know the building is not now 1,086 feet high. Thus, (8) is not a quasi-indicator sentence; its embedded clause does not express the proposition that Jones knew. But by virtue of now knowing (8), I now know the fact that Jones knew a proposition that was expressible, at noon, by a use of a sentence containing "now".

The reason for the locution "of this time" in (8) is that Jones' indexical reference to noon is not a de dicto reference but a de re reference. Jones did not know at noon that it was noon, June 17, 1989 but he did know at noon of noon, June 17, 1989 that it had presentness.

The result achieved is that the protophilosophical data requires us to modify Castañeda's theory of quasi-indicators in such a way as to render it consistent with the tensed theory of 
time. A task for another occasion is to situate these results in the context of Castañeda's Guise Theory. ${ }^{6}$

Recibido: 22 de marso de 1990

6 On the negative side, this task would involve showing how the protophilosophical data assembled in this paper are inconsistent with thesis that the quasi-indexical propositional guise expressed by a quasi-indicator sentence of the form "At $t, P$ knows (tenselessly) that $E$ occurred then" is "intimately equivalent" [TLE 157] to the indexical propositional guise expressed by a sentence of the form " $E$ occurs now" as uttered at $t$. On the positive side, it would evaluate the protophilosophical claims made in TLE 132-136, combine the results with data assembled in the present paper, and develop a tensed symphilosophy of A-guises (guises whose guise-core inclu$\operatorname{des} A$-properties of presentness, pastness or futurity) that holds these guises to be consubstantiated with the Leibnizian individuals that constitute the $B$-positions (the complete individual times) of the physical universe. 


\section{RESUMEN}

Este artículo es una discusión de la teoría de Castañeda de los cuasiindicadores temporales. El principio fundamental de dicha teoría es que el uso de expresiones indicadoras temporales (en especial, "ahora") en oraciones expresadas en estilo directo puede representarse por medio del uso de expresiones cuasi-indicadores temporales (en especial, "en ese momento") en oraciones expresadas en estilo indirecto. Así, las oraciones del primer tipo podrían ser puestas siempre en equivalencia semántica con oraciones del segundo tipo.

El autor señala que, de acuerdo con la manera en que Castañeda define las nociones de "indicador" y de "cuasi-indicador", su teoría es incompatible con una teoría temporalizada (tensed) del tiempo. Esto es, su teoría (a) niega que un enunciado temporalizado (tensed) de manera lógicamente contingente como, por ejemplo, "Se avecina una tormenta ahora" adscriba una propiedad monádica de presente, pasado o futuro, y, por lo mismo, (b) implica que un enunciado de ese tipo puede ser expresado en términos de un enunciado intemporal (tenseless). Dado (a) y dado que las expresiones cuasi-indicadoras no denotan, según Castañeda, ninguna propiedad monádica de tiempo, el uso de expresiones indicadoras temporales podría representarse a través del uso de ciertas expresiones cuasi-indicadoras. La argumentación del autor intenta mostrar (i) que la teoría de Castañeda no recoge de forma adecuada el significado pre-filosófico ni de las expresiones que Castañeda considera como cuasi-indicadoras ni de las expresiones consideradas comúnmente como indicadoras temporales y (ii) que para salvar la teoría de Castañeda es necesario modificarla al punto de volverla compatible con una teoría "temporal" (tensed) del tiempo.

En primer lugar, el autor entabla una discusión acerca de un famoso ejemplo ofrecido por Castañeda en "Omniscience and Indexical Reference". En el marco de esta discusión, el autor procura mostrar que, si atendemos al significado pre-filosófico del indicador "ahora", esta expresión denota una propiedad monádica de tiempo. Por lo tanto, si las expresiones cuasi-indicadoras no denotan ninguna propiedad monádica de tiempo, el principio fundamental mencionado antes de la teoría de los cuasi-indicadores es difícil de defender.

En segundo lugar, el autor examina una posible defensa del principio fundamental de la teoría de los cuasi-indicadores ante la ob- 
jeción anterior. Dicha defensa se desprende de la propuesta de Grim en "Against Omniscience: The Case from Essential Indexicals" y consiste en la interpretación de la categoría de "expresión cuasiindicadores" en términos de la categoría de "expresión adscriptiva de indicadores". Sin embargo, el autor señala que tampoco las oraciones en que figuran expresiones que caen bajo esta última categoría implican oraciones adscriptivas de propiedades monádicas de tiempo. Por lo tanto, el uso de expresiones indicadoras temporales difícilmente podría ser representado a través del uso de expresiones adscriptivas de indicadores.

Por último, el autor defiende la categoría de "cuasi-indicadores temporalizados (tensed)", la cual pone en duda la distinción ofrecida por Castañeda entre las nociones de "expresión indicadora" y "expresión cuasi-indicadora". De acuerdo con el autor, una expresión indicadora puede figurar en una oración en estilo indirecto que funcione como una expresión que, por ser capaz tanto de expresar una referencia indexical como de capturar el contenido semántico de esa referencia, Castañeda tendría que considerar cuasi-indicadora.

[Ricardo Salles] 